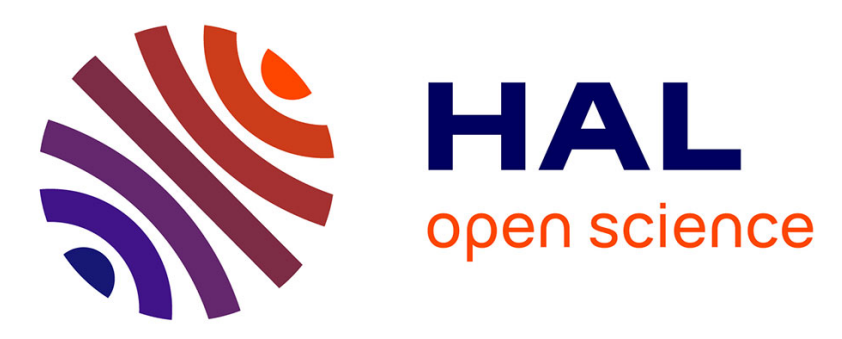

\title{
Silicon isotopic fractionation during adsorption of aqueous monosilicic acid onto iron oxide
}

Séverine Delstanche, Sophie Opfergelt, Damien Cardinal, Françoise Elsass, Luc André, Bruno Delvaux

\section{- To cite this version:}

Séverine Delstanche, Sophie Opfergelt, Damien Cardinal, Françoise Elsass, Luc André, et al.. Silicon isotopic fractionation during adsorption of aqueous monosilicic acid onto iron oxide. Geochimica et Cosmochimica Acta, 2009, 73 (4), pp.923-934. 10.1016/j.gca.2008.11.014 . hal-02665841

\section{HAL Id: hal-02665841 \\ https://hal.inrae.fr/hal-02665841}

Submitted on 31 May 2020

HAL is a multi-disciplinary open access archive for the deposit and dissemination of scientific research documents, whether they are published or not. The documents may come from teaching and research institutions in France or abroad, or from public or private research centers.
L'archive ouverte pluridisciplinaire HAL, est destinée au dépôt et à la diffusion de documents scientifiques de niveau recherche, publiés ou non, émanant des établissements d'enseignement et de recherche français ou étrangers, des laboratoires publics ou privés. 


\title{
Silicon isotopic fractionation during adsorption of aqueous monosilicic acid onto iron oxide
}

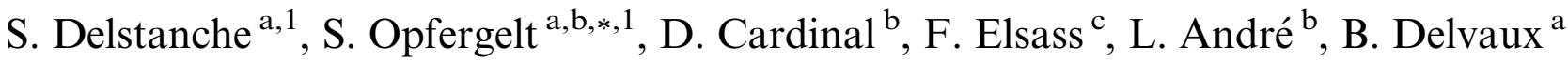 \\ ${ }^{a}$ Soil Science Unit, Université catholique de Louvain, Croix du Sud 2/10, B-1348 Louvain-la-Neuve, Belgium \\ ${ }^{\mathrm{b}}$ Dept. of Geology and Mineralogy, Musée Royal de l'Afrique Centrale, Leuvensesteenweg 13, B-3080 Tervuren, Belgium \\ ${ }^{\mathrm{c}}$ INRA, Science du Sol, Route de St-Cyr, Versailles 78026, France
}

Received 29 February 2008; accepted in revised form 11 November 2008

\begin{abstract}
The quantification of silicon isotopic fractionation by biotic and abiotic processes contributes to the understanding of the $\mathrm{Si}$ continental cycle. In soils, light $\mathrm{Si}$ isotopes are selectively taken up by plants, and concentrate in secondary clay-sized minerals. Si can readily be retrieved from soil solution through the specific adsorption of monosilicic acid $\left(\mathrm{H}_{4} \mathrm{SiO}_{4}{ }^{0}\right)$ by iron oxides. Here, we report on the $\mathrm{Si}$-isotopic fractionation during $\mathrm{H}_{4} \mathrm{SiO}_{4}{ }^{0}$ adsorption on synthesized ferrihydrite and goethite in batch experiment series designed as function of time $(0-504 \mathrm{~h})$ and initial concentration (ic) of Si in solution (0.21$1.80 \mathrm{mM})$, at $20^{\circ} \mathrm{C}$, constant $\mathrm{pH}(5.5)$ and ionic strength $(1 \mathrm{mM})$. At various contact times, the $\delta^{29} \mathrm{Si}$ vs. NBS28 compositions were determined in selected solutions (ic $=0.64$ and $1.06 \mathrm{mM} \mathrm{Si}$ ) by MC-ICP-MS in dry plasma mode with external Mg doping with an average precision of $\pm 0.08 \%$ oo $\left( \pm 2 \sigma_{\text {SEM }}\right)$. Per oxide mass, ferrihydrite (74-86\% of initial Si loading) adsorbed more Si than goethite (37-69\%) after $504 \mathrm{~h}$ of contact over the range of initial Si concentration $0.42-1.80 \mathrm{mM}$. Measured against its initial composition $\left(\delta^{29} \mathrm{Si}=+0.01 \pm 0.04 \%\left( \pm 2 \sigma_{\mathrm{SD}}\right)\right)$, the remaining solution was systematically enriched in ${ }^{29} \mathrm{Si}$, reaching maximum $\delta^{29} \mathrm{Si}$ values of $+0.70 \pm 0.07 \%$ for ferrihydrite and $+0.50 \pm 0.08 \%$ for goethite for ic $1.06 \mathrm{mM}$. The progressive ${ }^{29} \mathrm{Si}$ enrichment of the solution fitted better a Rayleigh distillation path than a steady state model. The fractionation factor ${ }^{29} \varepsilon\left( \pm 1 \sigma_{\mathrm{SD}}\right)$ was estimated at $-0.54 \pm 0.03 \%$ for ferrihydrite and $-0.81 \pm 0.12 \%$ for goethite. Our data imply that the sorption of $\mathrm{H}_{4} \mathrm{SiO}_{4}{ }^{0}$ onto synthetic iron oxides produced a distinct $\mathrm{Si}$-isotopic fractionation for the two types of oxide but in the same order than that generated by Si uptake by plants and diatoms. They further suggest that the concentration of light $\mathrm{Si}$ isotopes in the clay fraction of soils is partly due to $\mathrm{H}_{4} \mathrm{SiO}_{4}{ }^{0}$ sorption onto secondary clay-sized iron oxides.
\end{abstract}

(C) 2008 Elsevier Ltd. All rights reserved.

\section{INTRODUCTION}

Silicon is the second mass abundant element of Earth's crust and a major solute in river discharge into oceans (Tréguer et al., 1995; Gaillardet et al., 1999). Breakdown of primary silicates, translocation of $\mathrm{Si}$ in solution, formation of secondary silicates, and $\mathrm{Si}$ uptake by plants are involved in

\footnotetext{
* Corresponding author. Address: Soil Science Unit, Université catholique de Louvain, Croix du Sud 2/10, B-1348 Louvain-laNeuve, Belgium. Fax: +3210474525.

E-mail address: sophie.opfergelt@uclouvain.be (S. Opfergelt).

1 These authors contributed equally to this work, and are first coauthors cited by alphabetic order.
}

the continental cycle of Si. Dissolved Si is present as monosilicic acid $\left(\mathrm{H}_{4} \mathrm{SiO}_{4}{ }^{0}\right)$ in natural solutions (Lindsay, 1979), where it is commonly a major solute (McKeague and Cline, 1963). Apart from clay formation and uptake by biota, monosilicic acid can be withdrawn from soil solution through its sorption onto aluminum and iron oxides (Beckwith and Reeve, 1963; Jones and Handreck, 1963; McKeague and Cline, 1963). Iron oxides are ubiquitous in sediments, weathered rocks and soils (Schwertmann and Taylor, 1989), where they partly control the concentration of aqueous silicic acid (McKeague and Cline, 1963; Gehlen and Van Raaphorst, 2002). Their surface $\mathrm{OH}$ groups specifically interact with silicic acid by exchanging ligands to form a bi-dendate innersphere complex involving mono- 
meric $\mathrm{SiO}_{2}(\mathrm{OH})_{2}{ }^{2-}$ as main adsorbed species at low loading of aqueous Si (below $0.9 \mathrm{mM}$ ) (Hingston et al., 1967; Sigg and Stumm, 1981; Hansen et al., 1994b; Swedlund and Webster, 1999; Davis et al., 2002; Pokrovski et al., 2003; Hiemstra et al., 2007). At higher loading of aqueous $\mathrm{Si}$ $(>0.9 \mathrm{mM})$, however, Si tetramer can form on goethite surface (Hiemstra et al., 2007), whereas $\mathrm{H}_{4} \mathrm{SiO}_{4}{ }^{0}$ polymerization occurs on ferrihydrite surface at $\mathrm{H}_{4} \mathrm{SiO}_{4}{ }^{0}$ concentrations below those required for polymerization in solution (Swedlund and Webster, 1999). The adsorption of $\mathrm{Si}$ by $\mathrm{Fe}$ oxides strongly varies with $\mathrm{pH}$, and commonly reaches a maximum around $\mathrm{pH} 9$ (Jones and Handreck, 1963; Sigg and Stumm, 1981; Hansen et al., 1994a; Swedlund and Webster, 1999; Hiemstra et al., 2007).

Following weathering, iron oxides accumulate in soils (Bikerland, 1974), where they appear as both crystalline and short-range ordered (sro) minerals mainly in their clay-sized fraction (Schwertmann and Taylor, 1989). They can exert a crucial impact on the retention of $\mathrm{Si}$ and the control of aqueous $\mathrm{H}_{4} \mathrm{SiO}_{4}{ }^{0}$ (McKeague and Cline, 1963). Quantifying the fractionation of Si stable isotopes by biotic and abiotic processes readily contributes to the understanding of the continental cycle of $\mathrm{Si}$. As inferred from $\delta^{29} \mathrm{Si}$ and/or $\delta^{30} \mathrm{Si}$ values, river waters are depleted in light $\mathrm{Si}$ isotopes (De La Rocha et al., 2000; Ding et al., 2004; Alleman et al., 2005; Georg et al., 2006, 2007) compared with crustal rocks (Douthitt, 1982), following fractionating processes of silicate weathering and formation of clay-sized minerals (Ziegler et al., 2005a,b; Opfergelt et al., accepted for publication), silcrete formation (Basile-Doelsch et al., 2005), and Si uptake by biota (De La Rocha et al., 1997; Ding et al., 2005, 2008; Opfergelt et al., 2006a,b).

In this paper, we report on an experimental study on the isotope fractionation of $\mathrm{Si}$ by $\mathrm{H}_{4} \mathrm{SiO}_{4}{ }^{0}$ adsorption onto iron oxide. The experiments were designed to answer four questions of environmental significance: (1) Does Si isotope fractionation occur during $\mathrm{Si}$ adsorption onto Fe oxide at common pH for soil solutions? (2) How much does this fractionation compare with that generated by $\mathrm{Si}$ uptake by biota? Can this fractionation contribute to (3) the depletion of light $\mathrm{Si}$ isotopes in river waters, and (4) the enrichment of light $\mathrm{Si}$ isotopes in clay-sized soil fractions? For these purposes, we use goethite and ferrihydrite, crystalline and sro minerals, respectively. Our experimental study involves the prior synthesis and characterization of pure $\mathrm{Fe}$ oxides and the quantitative determination of $\mathrm{H}_{4} \mathrm{SiO}_{4}{ }^{0}$ adsorption in controlled conditions of temperature, solid:liquid ratio, $\mathrm{pH}$ and ionic strength.

\section{MATERIALS AND METHODS}

At all steps, acid-washed high density polyethylene (HDPE) ware and analytical grade Pro Analysi chemicals were used to minimize Si contamination.

\subsection{Synthesis and characterization of ferrihydrite and goethite}

Ferrihydrite and goethite were synthesized according to the methods described in Cornell and Schwertmann (1996).
For ferrihydrite, a freshly prepared $0.1 \mathrm{M} \mathrm{Fe}\left(\mathrm{NO}_{3}\right)_{3}$ solution $(250 \mathrm{ml})$ was slowly neutralized by $1 \mathrm{M} \mathrm{NaOH}$ $(70 \mathrm{ml})$, i.e. brought drop wise to $\mathrm{pH}$ 7.5. The red/brown precipitate was separated by centrifugation $(3500 \mathrm{rpm}$, $10 \mathrm{~min}$ ), dialyzed (dialysis-membrane SPECTRA/POR 4, $\mathrm{MWCO}=12-14000, \varnothing=29 \mathrm{~mm}$ ) against deionized water until electrical conductivity was stable at $1-2 \mu \mathrm{S}$ for $4 \mathrm{~h}$. The dialyzed product was freeze-dried. For goethite, a freshly prepared $1 \mathrm{M} \mathrm{Fe}\left(\mathrm{NO}_{3}\right)_{3}(100 \mathrm{ml})$ solution was neutralized by $5 \mathrm{M} \mathrm{NaOH}(70 \mathrm{ml})$ under intense stirring and brought to $\mathrm{pH}>12$. The red/brown precipitate was dried in the mother liquid at $70{ }^{\circ} \mathrm{C}$ for $60 \mathrm{~h}$, and turned to yellow/brown. The precipitate was washed with deionized water through washing-centrifugation cycles $(13,100 \mathrm{rpm}$, $15 \mathrm{~min}$ ) until $\mathrm{pH}$ and electrical conductivity were stable, respectively, at 5.5 and $1-2 \mu \mathrm{S}$. The precipitate was ovendried at $50{ }^{\circ} \mathrm{C}$ for $48 \mathrm{~h}$. Mineralogical and chemical characterizations of both products were done by (1) X-ray diffraction (XRD, Bruker D8 Advance diffractometer), (2) transmission electron microscopy (TEM, Philips 420 STEM), (3) elemental analysis (inductively coupled plasma/atomic emission spectrometry: ICP-AES, Jarrell Ash Iris Advantage) after $\mathrm{Na}_{2} \mathrm{O}_{2}$ fusion in vitrified graphite crucibles at $1000{ }^{\circ} \mathrm{C}$, (4) dithionite-citrate-bicarbonate extraction (DCB, Mehra and Jackson, 1960), (5) dark oxalate extraction (Blakemore et al., 1981), and (6) surface area determination using ethylene glycol monoethyl ether (EGME, Carter et al., 1965).

The X-ray diffraction (XRD) patterns were consistent with those for 2-line ferrihydrite and goethite in Cornell and Schwertmann (1996), and in Jambor and Dutrizac (1998) (Fig. 1). Observations by TEM revealed the common microaggregated shape of ferrihydrite, and the typical euhedral acicular crystals $(0.5-1.5 \mathrm{~mm}$ length) of goethite, constituted of parallel subunits (Fig. 2) (Schwertmann and Taylor, 1989; Cornell and Schwertmann, 1996). The content of poorly crystalline Fe was assessed through the determination of the ratio of oxalate extractable $\mathrm{Fe}\left(\mathrm{Fe}_{\mathrm{o}}\right)$ to DCB extractable $\mathrm{Fe}\left(\mathrm{Fe}_{\mathrm{d}}\right)$ (Cornell and Schwertmann, 1996) (Table 1). The $\mathrm{Fe}_{\mathrm{o}}: \mathrm{Fe}_{\mathrm{d}}$ ratio was 0.004 for goethite, certifying a well crystalline form, and 0.864 for ferrihydrite, attesting a large dominance of sro mineral particles. The average concentration of $\mathrm{Si}$ in the synthesized ferrihydrite and goethite was below $0.2 \mathrm{~g} \mathrm{~kg}^{-1}$ (Table 1), revealing the very low level of $\mathrm{Si}$ contamination. A specific extraction of initial adsorbed (i.e. potentially contaminating) Si by $\mathrm{KH}_{2} \mathrm{PO}_{4}$ (Delfosse et al., 2005) showed that this Si background was negligible and represents less than $0.5 \%$ of the total Si budget per experiment (Table 1). The EGME specific surface was 338 and $147 \mathrm{~m}^{2} \mathrm{~g}^{-1}$ for ferrihydrite and goethite, respectively.

\subsection{Adsorption experiments}

$\mathrm{H}_{4} \mathrm{SiO}_{4}{ }^{0}$ solutions were prepared by dissolving $\mathrm{Na}_{2}$ $\mathrm{SiO}_{3} \cdot 5 \mathrm{H}_{2} \mathrm{O}$ in MilliQ water, and further leaching on an $\mathrm{H}^{+}$cation exchanger (Amberlite ${ }^{\circledR}$ IR-120) to fix $\mathrm{Na}^{+}$ions. The leaching was terminated when the threshold level of sodium was below $10^{-2} \mathrm{mM} \mathrm{Na}$, as determined by ICP-AES (Henriet et al., 2006). The acidic Si stock solution 


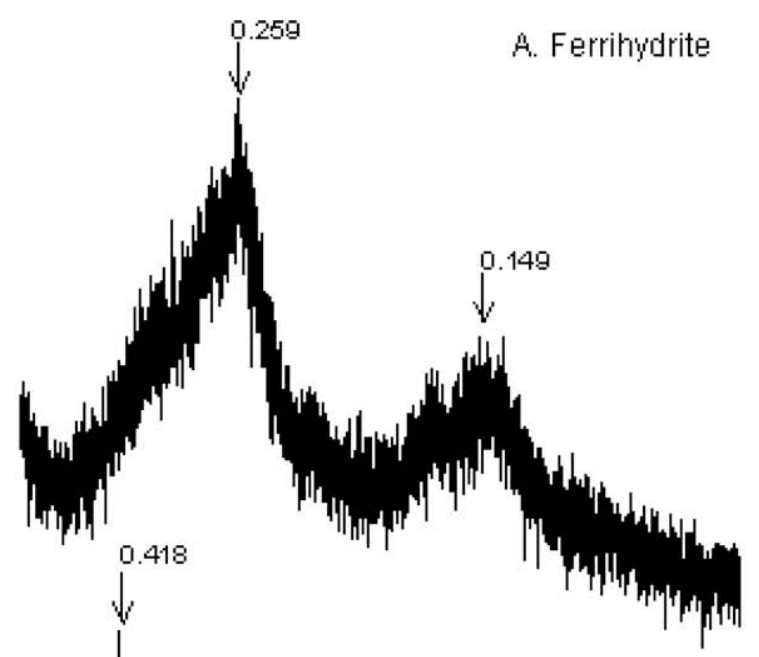

\section{B. Goethite}

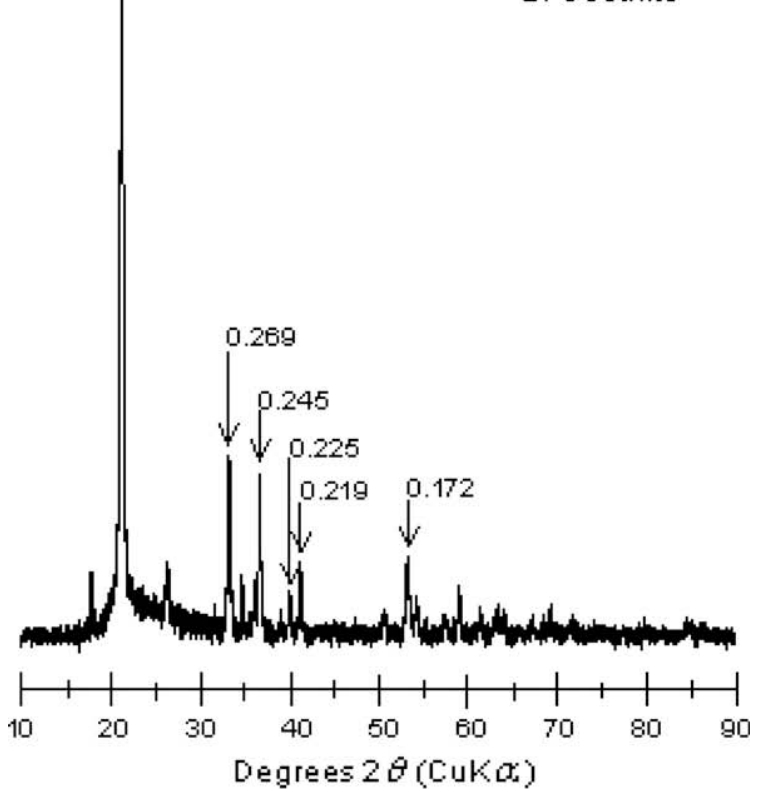

Fig. 1. $\mathrm{Cu} \mathrm{K} \alpha \mathrm{X}$-ray diffraction patterns of the synthesized (A) 2-line ferrihydrite and (B) goethite. Major peaks are labeled in $\mathrm{nm}$.
(35.61 mM Si, pH below 6) was free of polymers (Beckwith and Reeve, 1963; Stumm and Morgan, 1996). Eight solutions of distinct initial concentrations (ic) of Si were considered $0.21,0.42,0.64,0.85,1.06,1.29,1.49$ and $1.80 \mathrm{mM} \mathrm{Si}$. The ic solutions were prepared by using MilliQ water and pure $\mathrm{NaNO}_{3}$. A background electrolyte concentration of $1 \mathrm{mM} \mathrm{NaNO}$ was used throughout to maintain ionic strength constant. Contact between ic $\mathrm{Si}$ solution and $\mathrm{Fe}$ oxide was made in HDPE bottles, on a reciprocating shaker in a dark room at $20^{\circ} \mathrm{C}$. A suspension of $5 \mathrm{~g}$ of Fe oxide was transferred to a dialysis-membrane (SPECTRA/POR 4; MWCO 12-14,000; $\varnothing=16 \mathrm{~mm}$ ) and plunged in the $\mathrm{Si}$ solution of given ic. The initial solution volume was $1000 \mathrm{ml}$, as gravimetrically determined $(1 \mathrm{~g}: 250 \mathrm{ml}$ solid:liquid ratio). The $\mathrm{pH}$ was adjusted to the target $\mathrm{pH}$ $5.5 \pm 0.2$ by addition of $1 \mathrm{M} \mathrm{NaOH}$ or $0.7 \mathrm{M} \mathrm{HNO}_{3}$. The target $\mathrm{pH}$ value is common for natural waters in equilibrium with atmospheric $\mathrm{CO}_{2}$. The adsorption experiments were done in triplicates. Series 1 and 2 provided solution aliquots to determine the bulk concentrations of Si determined by ICP-AES (Jarrell Ash Iris Advantage, detection limit $<0.7 \mu \mathrm{M} \mathrm{Si}$ ). Adsorbed $\mathrm{Si}$ was computed as the difference between the Si solution concentrations before and after contact with Fe oxide. Series 3 was specifically devoted to the determination of $\mathrm{Si}$ isotopes. Solution aliquots $(10 \mathrm{ml})$ were sampled, respectively, after 6, 12, 24, 48, 72, 96, 192, 288, 408 and $504 \mathrm{~h}$ of contact time between Fe oxide and $\mathrm{Si}$ solution, and kept in HDPE bottles. The aliquots from each solution were transferred to polyethylene scintillation vials, then acidified by adding $50 \mu \mathrm{l}$ of $7 \mathrm{M} \mathrm{HNO}_{3}$ and stored in the dark at $4{ }^{\circ} \mathrm{C}$ prior to further analysis. During the experiment, $\mathrm{pH}$ was regularly checked and adjusted to the target when necessary, and systematically checked on a single series one hour prior to sampling solutions.

\subsection{Isotopic composition of solutions at given contact times}

Two ic solutions ( 0.64 and $1.06 \mathrm{mM} \mathrm{Si}$ ) and 20 solution aliquots from series 3 were selected on the basis of adsorption data with respect to detection limit required for $\mathrm{Si}$ isotope measurement. Dissolved $\mathrm{Si}$ in the chosen samples was purified by triethylamine molybdate co-precipitation and
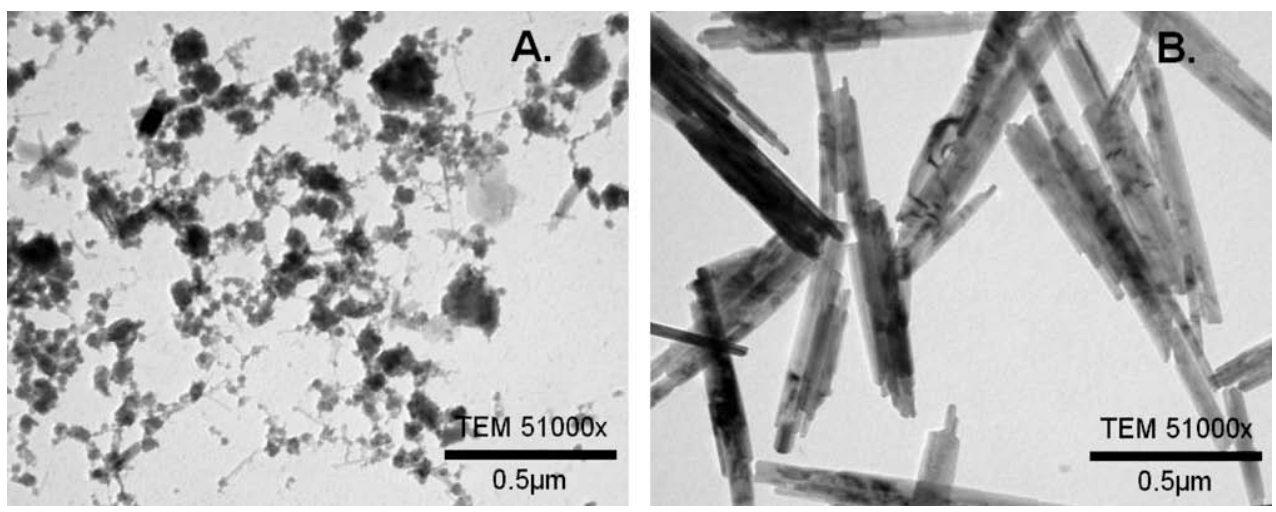

Fig. 2. TEM micrographs of the synthesized (A) 2-line ferrihydrite and (B) goethite (with a 51,000× magnification for both images), from aliquots of $<2 \mu \mathrm{m}$ suspensions left air-dried on a $\mathrm{C}$-coated $\mathrm{Cu}$-grid. 
Table 1

Chemical analysis of synthesized ferrihydrite and goethite: average contents of DCB (d) and oxalate (o) extractable Fe (Fe $\mathrm{d}_{\mathrm{d}}, \mathrm{Fe}_{\mathrm{o}}$; $\left.n=2\right)$, and of total $\mathrm{Si}\left(\mathrm{Si}_{\mathrm{t}} ; n=5\right)$, and $\mathrm{KH}_{2} \mathrm{PO}_{4}$ extractable $\mathrm{Si}$ content $\left(\mathrm{SiKH}_{2} \mathrm{PO}_{4}\right)$.

\begin{tabular}{llllll}
\hline & $\mathrm{Fe}_{\mathrm{d}}, \mathrm{g} \mathrm{kg}^{-1}$ & $\mathrm{Fe}_{\mathrm{o}}, \mathrm{g} \mathrm{kg}^{-1}$ & $\mathrm{Fe}_{\mathrm{o}}: \mathrm{Fe}_{\mathrm{d}}$ & $\mathrm{Si}_{\mathrm{t}}, \mathrm{g} \mathrm{kg}^{-1}$ & $\mathrm{SiKH}_{2} \mathrm{PO}_{4}, \mathrm{mg} \mathrm{kg}^{-1}$ \\
\hline Ferrihydrite & 594 & 513 & 0.864 & 0.12 & 5.7 \\
Goethite & 607 & 2.5 & 0.004 & 5.9 & 0.16 \\
\hline
\end{tabular}

combustion in covered Pt crucibles at $1000^{\circ} \mathrm{C}$ (De La Rocha et al., 1996), and dissolved in dilute suprapur $\mathrm{HF}-\mathrm{HCl}$ mixture (Cardinal et al., 2003). Si isotopes were measured using a $\mathrm{Nu}$ Plasma $\mathrm{MC}-\mathrm{ICP}-\mathrm{MS}$ operating in dry plasma mode, with an external $\mathrm{Mg}$ doping to correct mass bias (Cardinal et al., 2003). Due to unresolved isobaric interference on ${ }^{30} \mathrm{Si}$, only ${ }^{29} \mathrm{Si}$ and ${ }^{28} \mathrm{Si}$ isotopes were measured accurately (Cardinal et al., 2003). The analytical method was supported by an inter-laboratory comparison exercise and proved to be accurate on secondary reference materials (Reynolds et al., 2007). The average precision on $\delta^{29} \mathrm{Si}$ was $\pm 0.08 \%$ o $\left( \pm 2 \sigma_{\text {SEM }}\right)$. The results are presented as $\delta^{29} \mathrm{Si}(\%)$, expressing the ${ }^{29} \mathrm{Si} /{ }^{28} \mathrm{Si}$ ratios of our samples relative to the NBS28 silica sand standard (National Institute of Standard and Technology Reference Material \#8546) for silicon isotopes (Carignan et al., 2004):

$\delta^{29} \mathrm{Si}\left(\%_{0}\right)=\left[\frac{\left(\frac{{ }^{29} \mathrm{Si}}{{ }^{28} \mathrm{Si}}\right)_{\mathrm{sample}}}{\left(\frac{{ }^{29} \mathrm{Si}}{{ }^{28} \mathrm{Si}}\right)_{\mathrm{NBS} 28}}-1\right] * 1000$

Very small concentrations (below $0.5 \%$ of the total $\mathrm{Si}$ budget per experiment) of initial contaminating Si from mineral synthesis should not affect the isotopic composition of our solutions. Indeed, a significant contamination of $\pm 0.08 \%$ o (equivalent to our $2 \sigma_{\mathrm{SEM}}$ ) should be only induced by such contaminating Si bearing an isotopic composition lighter than $-48 \%$ or heavier than $+49 \%$, which is very unlikely regarding $\mathrm{Si}$-isotopic variations on Earth (BasileDoelsch, 2006).

\section{RESULTS AND DISCUSSION}

Mineralogical and chemical characterizations show that the separate synthesized products were genuine ferrihydrite and goethite minerals.

\subsection{Monomeric Si adsorption by ferrihydrite and goethite}

Only the average values of the duplicates are presented in following text, tables and figures. The error bars are systematically presented in the figures, and represent the experimental reproducibility. Table 2 presents the average bulk concentrations of $\mathrm{Si}$ in each solution corresponding to ferrihydrite and goethite, and to the respective eight ic solutions and 10 contact times. For both Fe oxides and each ic solution, the concentration of aqueous $\mathrm{Si}$ readily decreases with increasing contact time, revealing net $\mathrm{Si}$ adsorption. Below $\mathrm{pH}$ 9, the solution speciation of $\mathrm{H}_{4} \mathrm{SiO}_{4}{ }^{0}$ is $\mathrm{pH}$ independent, meaning that only aqueous $\mathrm{H}_{4} \mathrm{SiO}_{4}{ }^{0}$ was present in significant concentrations (Hiemstra et al., 2007). The systematic adjustment at $\mathrm{pH}$ $5.5 \pm 0.2$ required a larger addition of $\mathrm{NaOH}$ for ferrihydrite, indicating a net proton release during adsorption; the addition of $\mathrm{NaOH}$ was very low for goethite. In our controlled $\mathrm{pH}$ conditions, the $\mathrm{H}^{+}$release is likely caused by the specific interaction of $\mathrm{H}_{4} \mathrm{SiO}_{4}{ }^{0}$ with $\mathrm{OH}$ groups of oxide surface involving ligand exchange under formation of a $\mathrm{Fe}$ oxide-monosilicate surface complex $\left(\equiv \mathrm{Fe}_{2} \mathrm{O}_{2} \mathrm{Si}(\mathrm{OH})_{2}\right.$ bi-dendate complex) (Sigg and Stumm, 1981; Hansen et al., 1994a; Hiemstra et al., 2007). At Si

Table 2

Average values of $\mathrm{Si}$ concentration $(\mathrm{mM} \mathrm{Si})$ in solution as a function of contact time and type of $\mathrm{Fe}$ oxide for each initial $\mathrm{Si}$ concentration (time 0).

\begin{tabular}{llllllllllll}
\hline Time $(\mathrm{h})$ & 0 & 6 & 12 & 24 & 48 & 72 & 96 & 192 & 288 & 408 & 504 \\
\hline Ferrihydrite & 0.21 & 0.20 & 0.19 & 0.19 & 0.17 & 0.16 & 0.15 & 0.13 & 0.12 & 0.09 & 0.08 \\
& 0.42 & 0.39 & 0.38 & 0.35 & 0.31 & 0.27 & 0.24 & 0.15 & 0.14 & 0.10 & 0.08 \\
& 0.64 & 0.61 & 0.57 & 0.51 & 0.45 & 0.40 & 0.36 & 0.25 & 0.17 & 0.12 & 0.09 \\
& 0.85 & 0.79 & 0.75 & 0.69 & 0.60 & 0.53 & 0.47 & 0.31 & 0.23 & 0.17 & 0.13 \\
& 1.06 & 1.01 & 0.96 & 0.90 & 0.82 & 0.74 & 0.69 & 0.43 & 0.41 & 0.33 & 0.27 \\
& 1.29 & 1.21 & 1.16 & 1.07 & 0.97 & 0.88 & 0.81 & 0.61 & 0.47 & 0.38 & 0.32 \\
& 1.49 & 1.39 & 1.33 & 1.25 & 1.12 & 1.02 & 0.95 & 0.75 & 0.60 & 0.49 & 0.43 \\
& 1.80 & 1.68 & 1.62 & 1.55 & 1.43 & 1.33 & 1.23 & 0.99 & 0.81 & 0.65 & 0.56 \\
Goethite & 0.21 & 0.19 & 0.19 & 0.17 & 0.15 & 0.13 & 0.12 & 0.10 & 0.08 & 0.07 & 0.06 \\
& 0.42 & 0.39 & 0.37 & 0.33 & 0.29 & 0.25 & 0.22 & 0.16 & 0.15 & 0.14 & 0.13 \\
& 0.64 & 0.58 & 0.55 & 0.50 & 0.44 & 0.38 & 0.35 & 0.29 & 0.29 & 0.28 & 0.27 \\
& 0.85 & 0.80 & 0.78 & 0.72 & 0.65 & 0.60 & 0.57 & 0.49 & 0.47 & 0.45 & 0.43 \\
& 1.06 & 0.99 & 0.95 & 0.87 & 0.77 & 0.74 & 0.71 & 0.66 & 0.63 & 0.60 & 0.57 \\
& 1.29 & 1.18 & 1.14 & 1.08 & 1.00 & 0.95 & 0.90 & 0.83 & 0.79 & 0.77 & 0.73 \\
& 1.49 & 1.42 & 1.37 & 1.31 & 1.23 & 1.15 & 1.14 & 1.03 & 0.98 & 0.95 & 0.90 \\
& 1.80 & 1.71 & 1.65 & 1.58 & 1.49 & 1.43 & 1.37 & 1.28 & 1.23 & 1.08 & 1.13 \\
\hline
\end{tabular}


concentration above $\sim 0.2 \mathrm{mM}$, a surface $\mathrm{Si}$ tetramer $\left(\equiv \mathrm{Fe}_{2} \mathrm{O}_{2} \mathrm{SiOHOSi}_{3} \mathrm{O}_{3}(\mathrm{OH})_{9}\right)$ may have formed on goethite surface; at $\mathrm{pH} 5.5$, the proportion of this surface tetramer would be below $\sim 25 \%$, and the monomer species should be largely dominant (Hiemstra et al., 2007). The maximum value of the mole ratio of aqueous $\mathrm{Si}$ to ferrihydrite-Fe was 0.03 . In these conditions, the only significant surface bonding of $\mathrm{H}_{4} \mathrm{SiO}_{4}{ }^{0}$ with ferrihydrite surface should be the surface complexation of monomeric $\mathrm{H}_{4} \mathrm{SiO}_{4}{ }^{0}$ (Swedlund and Webster, 1999). This interpretation is consistent with the adsorption data performed at $\mathrm{pH}$ 3-6 by Hansen et al. (1994a).

\subsection{Quantitative Si adsorption by ferrihydrite and goethite}

In fixed conditions of $\mathrm{pH}$, ionic strength, temperature and solid:liquid ratio, the $\mathrm{Si}$ amount adsorbed depends on reaction time and type of $\mathrm{Fe}$ oxide (Hansen et al., 1994a). Per oxide mass, ferrihydrite generally adsorbs more Si than goethite (Table 2). After $504 \mathrm{~h}$ of contact between Fe oxide and $\mathrm{Si}$ solution, the fraction of adsorbed $\mathrm{Si}$ ranges between $63 \%$ and $86 \%$ for ferrihydrite, and between $37 \%$ and $72 \%$ for goethite (Fig. 3). Few studies have shown a larger $\mathrm{Si}$ adsorption by ferrihydrite over goethite (Hansen et al., 1994a), or by amorphous over crystalline Fe oxide (Jones and Handreck, 1963). Surface reactivity for oxyanions, weak acids and water is well known to decrease with increasing Fe oxide crystallinity (Parfitt, 1978; Schwertmann et al., 1985; Schwertmann and Taylor, 1989; Cornell and Schwertmann, 1996). As crystallinity increases, oxide crystals become larger and surface area decreases (Schwertmann et al., 1985). As measured by EGME retention, the surface area was $338 \mathrm{~m}^{2} \mathrm{~g}^{-1}$ for ferrihydrite and $147 \mathrm{~m}^{2} \mathrm{~g}^{-1}$ for goethite (Section 2.1). As expected (Cornell and Schwertmann, 1996), these EGME values are generally above BET- $\mathrm{N}_{2}$ values previously measured for synthesized Fe oxides: $35-87 \mathrm{~m}^{2} \mathrm{~g}^{-1}$ for goethite (Hansen et al., 1994a; Waltham and Eick, 2002; Garman et al., 2004; Luxton et al., 2006), 269-380 $\mathrm{m}^{2} \mathrm{~g}^{-1}$ for ferrihydrite (Hansen et al., 1994a,b; Hofmann et al., 2004). In agreement with Cornell and Schwertmann (1996), we believe, however, that there is large uncertainty about the surface area measurement of hydrous hydroxyl-bearing $\mathrm{Fe}$ oxide because this measurement requires a prior anhydrous vacuum. This conditioning can, indeed, modify surface particle, particle size and porosity through particle microaggregation (Hofmann et al., 2004).

The adsorption data are illustrated at $504 \mathrm{~h}$ contact time in Fig. 4. The data could be fitted to Freundlich, Langmuir, Temkin and Redlich-Peterson adsorption isotherms (not shown). For goethite, the adsorption data $(\mathrm{Q}, \mathrm{C})$ best fit a Freundlich isotherm expressed as:

$\mathrm{Q}=K_{F} \mathrm{C}^{1 / n}$

where $\mathrm{Q}$ is the $\mathrm{Si}$ adsorbed per unit mass of oxide (mmol Si $\left.\mathrm{g}^{-1}\right), K_{F}$ and $n$ are empirical constants and $\mathrm{C}$ the $\mathrm{H}_{4} \mathrm{SiO}_{4}{ }^{0}$ concentration of the solution (mM Si). This empirical model has been considered to be thermodynamically consistent with sorption on heterogeneous surfaces that imply different sorption sites and affinities (Weber et al., 1991). However, this is also consistent with the fact that the positive charge of $\mathrm{Fe}$ oxide surface decreases with the increase in the surface Si loading (Hingston et al., 1972; Anderson and Benjamin, 1985; Hiemstra et al., 2007), since the net proton release leads to a shift in the isoelectric point of Fe oxide (Garman et al., 2004; Luxton et al., 2006). For ferrihydrite, the adsorption data best fit a Temkin isotherm expressed as

$\mathrm{Q}=A+B \ln \mathrm{C}$

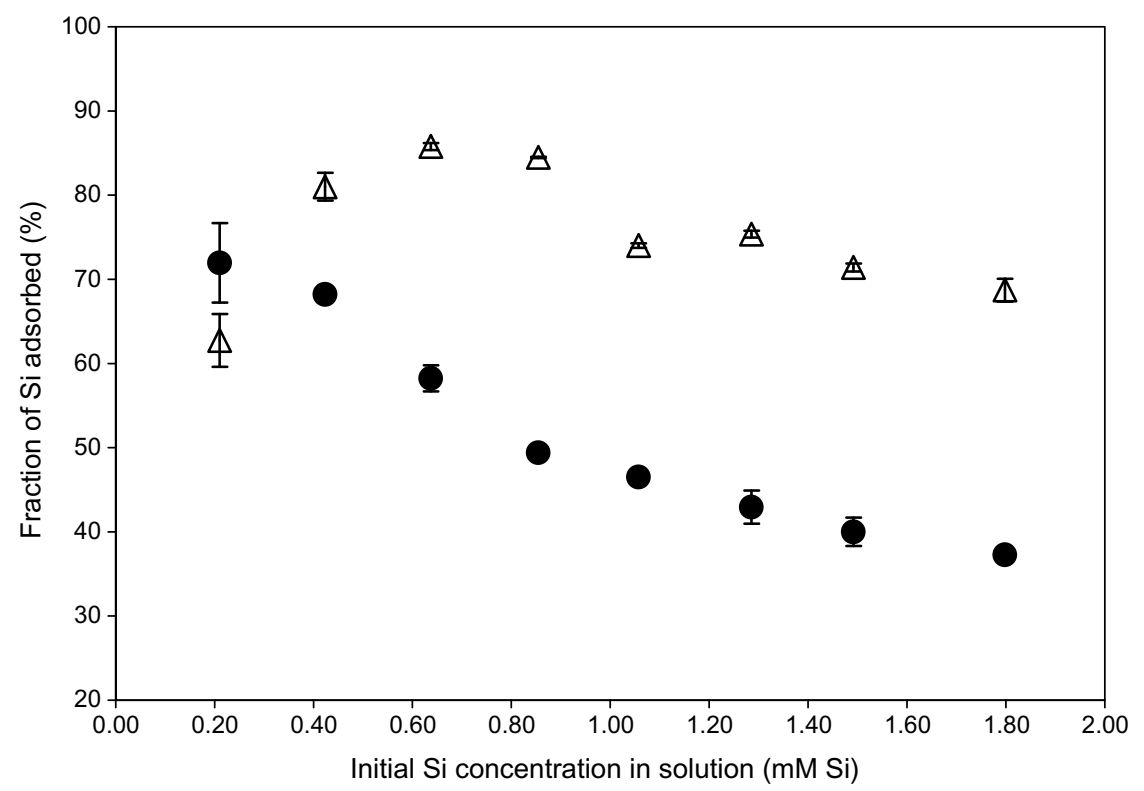

Fig. 3. Average values $(n=2)$ of adsorbed $\mathrm{Si}$, expressed as a fraction of initial $\mathrm{Si}$ after $504 \mathrm{~h}$ of contact. Ferrihydrite: open triangle. Goethite: full circle. Plotted error bar corresponds to standard deviation between series 1 and 2. 


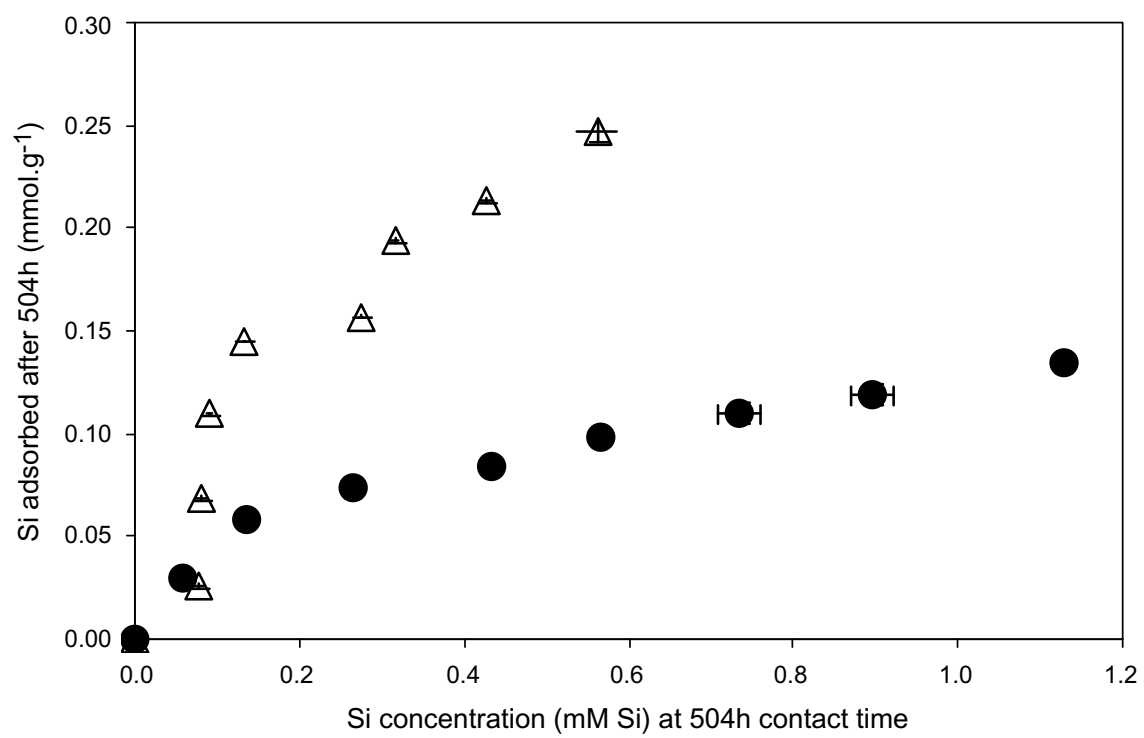

Fig. 4. Average values of $\mathrm{Si}$ adsorbed $(n=2)$ as a function of $\mathrm{Si}$ concentration of the solution after $504 \mathrm{~h}$ contact time. Ferrihydrite: open triangle. Goethite: full circle. Plotted error bar corresponds to standard deviation between series 1 and 2.

where $\mathrm{Q}$ and $\mathrm{C}$ are defined as in Eq. (2), and $A$ and $B$ are constants determined through linear regression from experimental data. For both ferrihydrite and goethite, the Temkin equation implies the condition that the energy of adsorption decreases linearly with surface coverage (Parfitt, 1978). This is consistent with the decrease of charge density as proposed for goethite. As discussed above, the much larger adsorption of $\mathrm{Si}$ on ferrihydrite in the range 0.1$0.6 \mathrm{mM} \mathrm{Si}$ is attributed to the larger availability of reactive sites in ferrihydrite relatively to goethite.

\subsection{Adsorption kinetics}

$\mathrm{Si}$ adsorption increases with time, first rapidly, then slower (Table 2). The time dependent adsorption of Si by $\mathrm{Fe}$ oxide is illustrated for the ic solutions 0.64 and $1.06 \mathrm{mM} \mathrm{Si}$ (Fig. 5). Si adsorption requires days-weeks. The rate of adsorption is rather large during the first hours ( $\sim 50 \mathrm{~h}$ for goethite, $\sim 100 \mathrm{~h}$ for ferrihydrite), then decreases. After $\sim 200 \mathrm{~h}$ for goethite and $\sim 300 \mathrm{~h}$ for ferrihydrite, it seems to reach a constant value, which increases from goethite to ferrihydrite with increasing aqueous $\mathrm{Si}$ concentration. These observations are in very good agreement with previous results (Hansen et al., 1994a,b). The change in the rate of $\mathrm{Si}$ adsorption onto ferrihydrite is similar to that observed for phosphate (Lijklema, 1980; Bolan et al., 1985). The slow adsorption step for phosphate has been attributed to diffusion into interparticle pores (Willett et al., 1988), whereas arsenate adsorption onto ferrihydrite has been successfully predicted using a pore-space diffusion model and assuming rapid adsorption at external surfaces of aggregates (Fuller et al., 1993). Accordingly, and in agreement with Hansen et al. (1994b), the rate of Si adsorption observed here is probably controlled by rapid interaction of monosilic acid with external oxide surface sites, and by slower interparticle diffusion.

\subsection{Si-isotopic fractionation during adsorption of monosilic acid}

The selected solutions correspond to the ic solutions 0.64 and $1.06 \mathrm{mM} \mathrm{Si}$ at various contact times ranging, respectively, between 0 and $192 \mathrm{~h}$, and 0 and $504 \mathrm{~h}$. The values of Si concentration in the selected solutions at $\mathrm{pH} 5.5$ range between 0.25 and $0.96 \mathrm{mM} \mathrm{Si}$ (Table 2). These conditions of $\mathrm{pH}$ and Si concentration imply a dominant adsorption of monomeric Si (Sigg and Stumm, 1981; Hansen et al., 1994a,b; Swedlund and Webster, 1999; Hiemstra et al., 2007), but do not exclude the occurrence of a surface $\mathrm{Si}$ tetramer on goethite surface. For Si solutions oversaturated with respect to quartz $\left(K_{S}>\sim 0.12 \mathrm{mM} \mathrm{Si}\right)$, the proportion of surface $\mathrm{Si}$ tetramer was estimated below $15 \%$ for $\mathrm{Si}$ concentration below $\sim 1 \mathrm{mM}$ Si (Hiemstra et al., 2007).

The Si-isotopic compositions of the selected solutions are given in Table 3 . Generally the $\delta^{29}$ Si value significantly increases with increasing time, and thus with decreasing $\mathrm{Si}$ concentration of the solution at various contact times. This increase involves a gradual fractionation of stable Si isotopes, revealing a depletion of the aqueous phase in light $\mathrm{Si}$ isotopes which parallels the adsorption of monosilicic acid onto $\mathrm{Fe}$ oxide. Measured against its initial composition $\left(+0.01 \pm 0.04 \%\right.$ oo $\left.\left( \pm 2 \sigma_{\mathrm{SD}}\right)\right)$, the solution is indeed systematically enriched with the heavy isotope, reaching a maximum $\delta^{29} \mathrm{Si}$ value of $+0.70 \pm 0.07 \%$ for ferrihydrite and $+0.50 \pm 0.08 \%$ for goethite at ic $1.06 \mathrm{mM} \mathrm{Si}$ after $504 \mathrm{~h}$ of contact. For ferrihydrite at ic $0.64 \mathrm{mM} \mathrm{Si}$, solution at $72 \mathrm{~h}$ displays lighter $\mathrm{Si}$-isotopic compositions than solution at $48 \mathrm{~h}$, unlike the general increase of $\delta^{29} \mathrm{Si}$ in solution with time in other treatments (Table 3 ). This shift down might be attributed to a possible abnormal variation of $\mathrm{pH}$ during the experiment at $72 \mathrm{~h}$ in this series (series 3 was used exclusively for isotopic measurements and therefore $\mathrm{pH}$ was not 


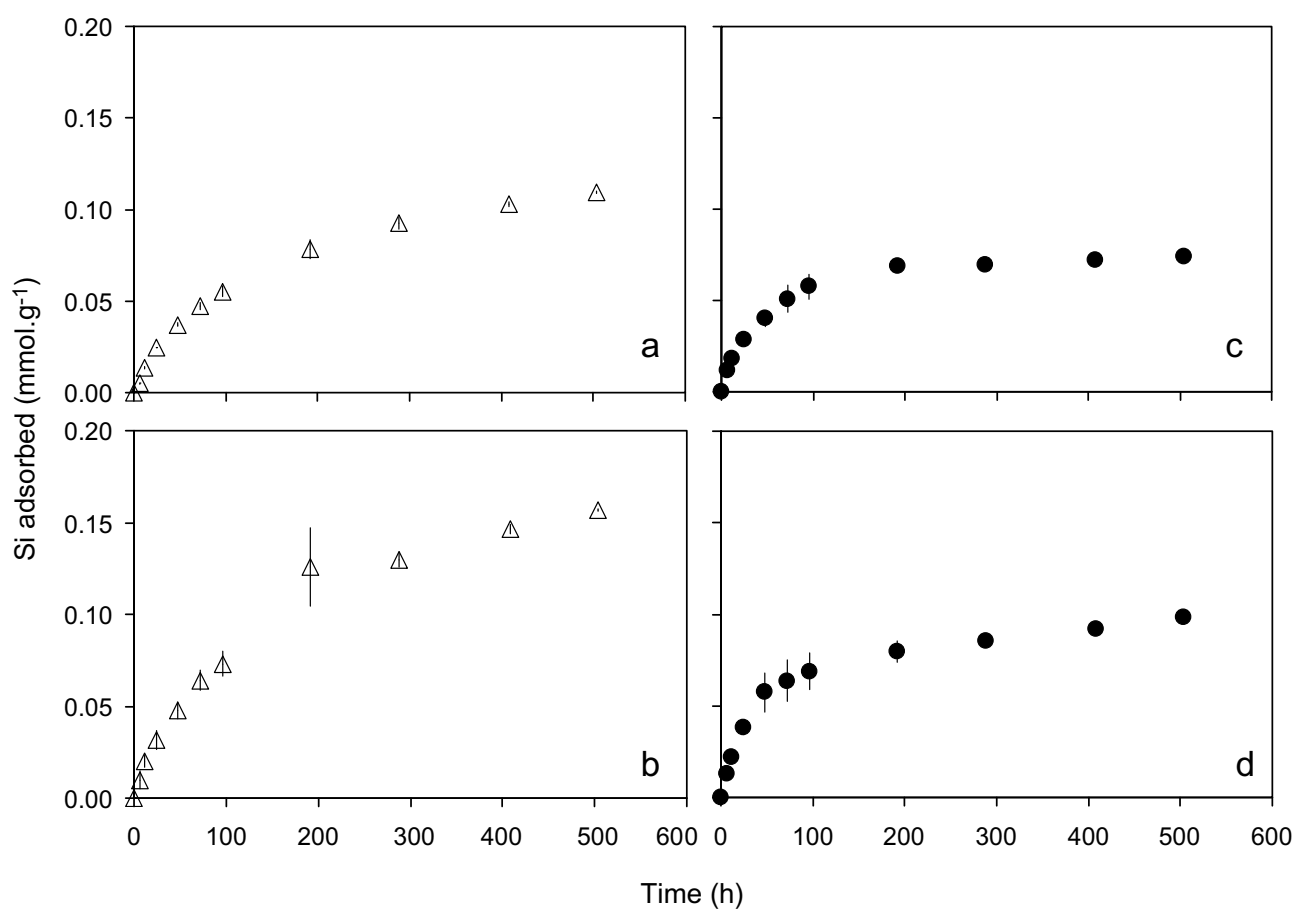

Fig. 5. Average values of the concentration of $\mathrm{Si}$ adsorbed $(n=2)$ by ferrihydrite (a: $0.64 \mathrm{mM} \mathrm{Si}$ ic $-\mathrm{b}: 1.06 \mathrm{mM} \mathrm{Si}$ ic) and goethite (c: $0.64 \mathrm{mM} \mathrm{Si}$ ic $-\mathrm{d}: 1.06 \mathrm{mM} \mathrm{Si}$ ic), as a function of contact time. Plotted error bar corresponds to standard deviation between series 1 and 2.

Table 3

Measured Si-isotopic composition $\left(\delta^{29} \mathrm{Si}\right.$ vs. NBS28) of the solution, as a function of initial $\mathrm{Si}$ concentration $(0.64 \mathrm{mM}$ and $1.06 \mathrm{mM} \mathrm{Si})$, contact time (h) and type of Fe oxide.

\begin{tabular}{|c|c|c|c|c|c|c|}
\hline & \multicolumn{3}{|c|}{$0.64 \mathrm{mM}$} & \multicolumn{3}{|c|}{$1.06 \mathrm{mM}$} \\
\hline & $\begin{array}{l}\text { Time, } \\
\mathrm{h}\end{array}$ & $\begin{array}{l}\delta^{29} \mathrm{Si} \\
\% \text { o }\end{array}$ & $\begin{array}{l}\text { St error } \\
2 \sigma_{\text {SEM }}\end{array}$ & $\begin{array}{l}\text { Time, } \\
\mathrm{h}\end{array}$ & $\begin{array}{l}\delta^{29} \mathrm{Si} \\
\% \text { o }\end{array}$ & $\begin{array}{l}\text { St error } \\
2 \sigma_{\text {SEM }}\end{array}$ \\
\hline \multirow[t]{6}{*}{ Ferrihydrite } & 0 & +0.02 & 0.07 & 0 & +0.00 & 0.09 \\
\hline & 12 & +0.07 & 0.09 & 12 & +0.01 & 0.06 \\
\hline & 24 & +0.13 & 0.10 & 48 & +0.11 & 0.09 \\
\hline & 48 & +0.21 & 0.08 & 96 & +0.22 & 0.09 \\
\hline & $72^{*}$ & +0.10 & 0.11 & 288 & +0.54 & 0.09 \\
\hline & $192^{*}$ & +0.27 & 0.07 & 504 & +0.70 & 0.07 \\
\hline \multirow[t]{6}{*}{ Goethite } & 0 & +0.02 & 0.07 & 0 & +0.00 & 0.09 \\
\hline & 12 & +0.00 & 0.08 & 12 & +0.02 & 0.07 \\
\hline & 24 & +0.13 & 0.08 & 48 & +0.12 & 0.09 \\
\hline & 48 & +0.26 & 0.08 & 96 & +0.21 & 0.09 \\
\hline & 72 & +0.27 & 0.07 & 288 & +0.34 & 0.09 \\
\hline & 192 & +0.66 & 0.07 & 504 & +0.50 & 0.08 \\
\hline
\end{tabular}

* These values were excluded from the ${ }^{29} \varepsilon$ calculation (see text and Table 4).

directly measured in it, see Section 2.3). A pH variation may have likely influenced the isotopic composition of the solutions at contact time $\geqslant 72 \mathrm{~h}$, because $\mathrm{pH}$ affects the adsorption of $\mathrm{Si}$ onto $\mathrm{Fe}$ oxide (Jones and Handreck, 1963). The two measurements at 72 and $192 \mathrm{~h}$ will thus not be considered in further calculations and interpretation. The isotopic composition of the solution can be predicted by following models, generally used to describe biologically driven $\mathrm{Si}$-isotopic fractionation:

The Rayleigh model following:

$$
\delta^{29} \mathrm{Si}_{\text {solution }}=\delta^{29} \mathrm{Si}_{\text {initial }}+{ }^{29} \varepsilon_{\mathrm{R}} \ln f
$$

The steady state model following:

$\delta^{29} \mathrm{Si}_{\text {solution }}=\delta^{29} \mathrm{Si}_{\text {initial }}-{ }^{29} \varepsilon_{\mathrm{S}}(1-f)$

where $\delta^{29} \mathrm{Si}_{\text {initial }}$ and $\delta^{29} \mathrm{Si}_{\text {solution }}$ are, respectively, measured in the ic solution and the solution at each contact time (Table 3), $f$ is the fraction of Si remaining in solution at each contact time (Table 2), and ${ }^{29} \varepsilon$ is the fractionation factor ( $\mathrm{R}$ for Rayleigh, $\mathrm{S}$ for steady state).

In order to decipher between the two models, best fits curves have been estimated based on three isotopic measurements of the beginning of each time series experiments ( $f=1, \sim 0.8$ and $\sim 0.7$ ) where both models are still not distinguishable compared to the analytical standard error (calculated ${ }^{29} \varepsilon$ in Table $4 \mathrm{~A}$ ). The experimental data were plotted on those best fit curves (Fig. 6). This indicated a preferential Rayleigh process rather than a steady state model for ferrihydrite at $1.06 \mathrm{mM} \mathrm{Si}$ (Fig. 6b), and also though in a less extent a Rayleigh process for goethite at both 0.64 and $1.06 \mathrm{mM} \mathrm{Si} \mathrm{(Fig.} \mathrm{6c} \mathrm{and} \mathrm{d).}$

To further reduce the uncertainty on the fractionation factor ${ }^{29} \varepsilon$, more estimates have then been calculated from Rayleigh Eq. (4) using all experimental data available (Table 4B). The errors associated to the use of Eq. (4) to derive a fractionation factor are discussed in Scott et al. (2004). In the case of our $\delta^{29} \mathrm{Si}$ values, these errors are however not significant due to analytical limitations. Therefore, the 
Table 4

Values of the fractionation factor ${ }^{29} \varepsilon \pm 1 \sigma_{\mathrm{SD}}$ computed following Rayleigh model (R) and steady state model (S) from Eqs. (4) and (5): (A) on three isotopic measurements of the beginning of each time series experiments (at $f=1, \sim 0.8, \sim 0.7$ ); (B) on the whole data set for each experiment.

\begin{tabular}{llllll}
\hline & $\mathrm{A}$ & & $\mathrm{B}$ & \\
\cline { 2 - 3 } \cline { 5 - 6 } & Rayleigh ${ }^{29} \varepsilon_{\mathrm{R}} \pm 1 \sigma_{\mathrm{SD}}$ & Steady state ${ }^{29} \varepsilon_{\mathrm{S}} \pm 1 \sigma_{\mathrm{SD}}$ & & Rayleigh ${ }^{29} \varepsilon_{\mathrm{R}} \pm 1 \sigma_{\mathrm{SD}}$ & Steady state ${ }^{29} \varepsilon_{\mathrm{S}} \pm 1 \sigma_{\mathrm{SD}}$ \\
\hline Ferrihydrite $0.64 \mathrm{mM}^{*}$ & $-0.53 \pm 0.04$ & $-0.62 \pm 0.07$ & $-0.54 \pm 0.03$ & $-0.63 \pm 0.06$ \\
Goethite $0.64 \mathrm{mM}$ & $-0.59 \pm 0.14$ & $-0.70 \pm 0.19$ & $-0.84 \pm 0.13$ & $-1.16 \pm 0.26$ \\
Ferrihydrite $1.06 \mathrm{mM}$ & $-0.51 \pm 0.05$ & $-0.61 \pm 0.10$ & $-0.55 \pm 0.02$ & $-0.99 \pm 0.08$ \\
Goethite $1.06 \mathrm{mM}$ & $-0.49 \pm 0.11$ & $-0.58 \pm 0.15$ & $-0.78 \pm 0.11$ & $-1.01 \pm 0.19$ \\
\hline
\end{tabular}

${ }^{*}$ Excluding the $\delta^{29} \mathrm{Si}$ measured at 72 and $192 \mathrm{~h}$ (see text and Table 3 ).

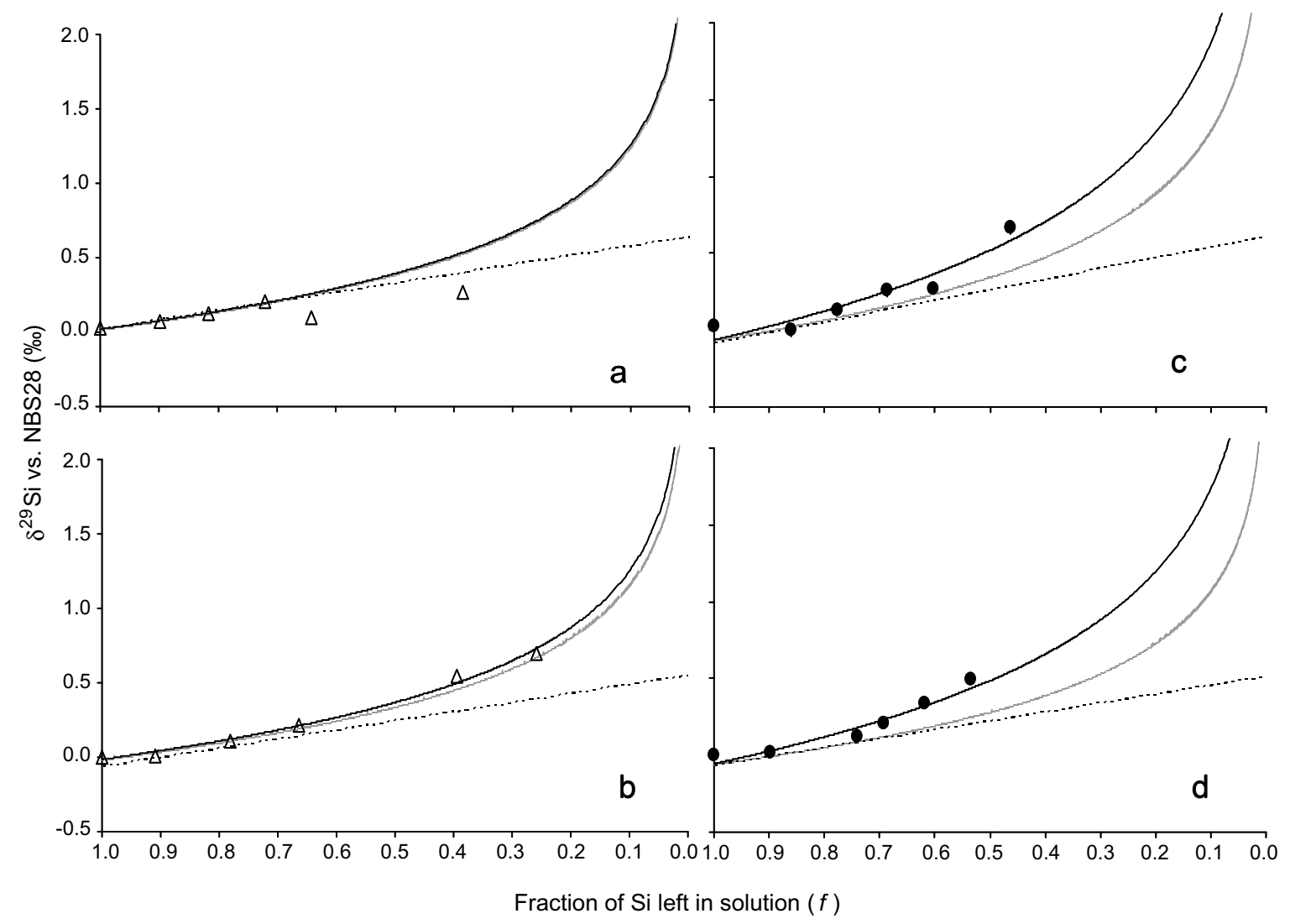

Fig. 6. Measured Si-isotopic composition $\left(\delta^{29} \mathrm{Si}\right.$ vs. NBS28) of the solution, as a function of the fraction of Si left in solution at various contact times (see Table 3), for ferrihydrite (a: $0.64 \mathrm{mM} \mathrm{Si} \mathrm{ic} \mathrm{-} \mathrm{b:} 1.06 \mathrm{mM} \mathrm{Si}$ ic) and goethite (c: $0.64 \mathrm{mM} \mathrm{Si}$ ic - d:1.06 mM Si ic). The error bar ( $2 \sigma_{\mathrm{SEM}}$ on single delta measurement) is included into the size of the symbol. The experimental data are compared with best fits following: (i) Rayleigh (exponential gray line) and steady state (linear dotted line) fractionation models based on three isotopic measurements at the beginning of the experiment (Table 4A); (ii) Rayleigh model (exponential black full line) based on all isotopic data available (Table 4B).

uncertainty on ${ }^{29} \varepsilon$ is calculated as the error on the slope $\left(1 \sigma_{\mathrm{SD}}\right)$ of $\delta^{29} \mathrm{Si}_{\text {solution }}$ data plotted against $\ln f$ for Rayleigh including propagated analytical uncertainty. It was calculated using the REG procedure of the SAS System (version 9.1 for Windows, SAS Institute, Cary, NC, USA). Following the Rayleigh model, ${ }^{29} \varepsilon_{\mathrm{R}}\left( \pm 1 \sigma_{\mathrm{SD}}\right)$ ranges between $-0.54 \pm 0.03 \%$ and $-0.55 \pm 0.02 \%$ for ferrihydrite, and between $-0.84 \pm 0.13 \%$ and $-0.78 \pm 0.11 \%\left( \pm 1 \sigma_{\mathrm{SD}}\right)$ for goethite, for ic 0.64 and $1.06 \mathrm{mM}$, respectively (Table 4B). The fractionation factor ${ }^{29} \varepsilon_{\mathrm{R}}$ does not differ between ic solutions for a given oxide, but is significantly larger for goethite than for ferrihydrite. Estimates from the steady state model are also given in Table 4B (with uncertainty as the error on the slope of $\delta^{29} \mathrm{Si}_{\text {solution }}$ data plotted against $(1-f)$ ), from which we deduce that (i) the uncertainty on the Rayleigh ${ }^{29} \varepsilon_{\mathrm{R}}$ fractionation factor is much smaller than the one reckoned for a steady state fractionation $\left({ }^{29} \varepsilon_{S}\right)$, confirming our deduction drawn from the first calculation, (ii) change of ic does not affect ${ }^{29} \varepsilon_{\mathrm{R}}$ neither for ferrihydrite nor for goethite.

Averaging our two groups of experiments at both ic solutions, our best estimates of ${ }^{29} \varepsilon_{\mathrm{R}}\left( \pm 1 \sigma_{\mathrm{SD}}\right)$ are computed 
at $-0.54 \pm 0.03 \%$ for ferrihydrite and $-0.81 \pm 0.12 \%$ for goethite.

\section{IMPLICATIONS}

\subsection{Mechanisms of isotopic fractionation}

Our ${ }^{29} \varepsilon_{R}$ values following Rayleigh model (Table 4B) show that the $\mathrm{Si}$-isotopic fractionation induced by $\mathrm{H}_{4} \mathrm{SiO}_{4}{ }^{0}$ adsorption onto $\mathrm{Fe}$ oxide is similar or slightly larger to the one generated by biological processes such as $\mathrm{Si}$ uptake by plants $\left({ }^{29} \varepsilon \pm 1 \sigma_{\mathrm{SD}}=-0.53 \pm 0.17 \%\right.$, Ding et al., $2005 ;-0.52 \pm 0.16 \%$, Ziegler et al., 2005a; $-0.40 \pm 0.11 \%$, Opfergelt et al., 2006a) and diatoms $\left({ }^{29} \varepsilon=-0.57 \pm 0.21 \%\right.$, De La Rocha et al., 1997).

According to Barling and Anbar (2004), the adequacy of the Rayleigh fit within our type of experimental design would indicate an irreversible adsorption process, which would suggest a kinetic isotope effect, and thus could be associated with (i) the variation of $\mathrm{Si}$ adsorption rate (Fig. 4 and Table 3), and (ii) the poor reversibility of $\mathrm{Si}$ adsorption through ligand exchange (Parfitt, 1978). However, we have no implemented an experimental design to test the irreversibility. Yet, in our scheme, isotope fractionation can result from (i) an equilibrium fractionation between coexisting aqueous species coupled with a selective sorption of one of them (Siebert et al., 2003), (ii) the formation of inner sphere surface complexes (Lemarchand et al., 2007). In this respect, light boron isotope enrichment on goethite is strongly dependent on $\mathrm{pH}$ and surface complex structure (Lemarchand et al., 2007). Here, the equilibrium fractionation process between coexisting aqueous species could be discarded because $\mathrm{H}_{4} \mathrm{SiO}_{4}{ }^{0}$ is the only significant aqueous $\mathrm{Si}$ species in our experimental conditions (see Section 3.1). The Ge isotopic fractionation during Ge sorption onto goethite privileges the selective sorption of light $\mathrm{Ge}$ isotopes, and has been successfully modeled by surface complexation involving the interaction of monomeric $\mathrm{Ge}$ hydro-complexes with $>\mathrm{FeOH}^{0}$ and $>\mathrm{FeO}^{-}$sites of goethite (Galy et al., 2002). These complexes have been further experimentally identified as Ge bi-dendate surface complexes composed of tetrahedrally coordinated Ge attached to the corners of two adjacent Fe octahedra (Pokrovsky et al., 2006). Here, we tentatively propose that the Si-isotopic fractionation induced by $\mathrm{H}_{4} \mathrm{SiO}_{4}{ }^{0}$ sorption onto ferrihydrite and goethite is caused by the formation of Fe oxidemonosilicate bi-dendate inner surface complexes $\left(\equiv \mathrm{Fe}_{2} \mathrm{O}_{2} \mathrm{Si}(\mathrm{OH})_{2}\right)$ (Sigg and Stumm, 1981; Hansen et al., 1994a; Dietzel, 2002; Hiemstra et al., 2007). However, surface $\mathrm{Si}$ polymerization, according to the definition of McBride (1994), cannot be disregarded, as the occurrence of Si tetramer has been predicted on goethite surface for $\mathrm{Si}$ solutions oversaturated with respect to quartz ( 0.12 mM Si) (Hiemstra et al., 2007) (see Section 3.1). This would hypothetically contribute to increase $\mathrm{Si}$ isotope fractionation for goethite relatively to ferrihydrite, for which the only significant surface bonding of $\mathrm{H}_{4} \mathrm{SiO}_{4}{ }^{0}$ should be the surface complexation of monomeric $\mathrm{H}_{4} \mathrm{SiO}_{4}{ }^{0}$ (Hansen et al., 1994a,b; Swedlund and Webster, 1999). Such a hypothesis would fit with the enrichment of light $\mathrm{Si}$ isotopes observed in the clay-sized fraction of soils with increasing weathering (Ziegler et al.,2005a,b; Opfergelt et al., accepted for publication) suggesting that clay formation may privilege light $\mathrm{Si}$ isotopes. Indeed, such formation in soil environment requires $\mathrm{Si}$ polymerization at low pressure and temperature. These hypotheses need, however, both further in-depth field-based investigations and a theoretical evaluation of the size of the isotopic energy shifts between soluble $\mathrm{H}_{4} \mathrm{SiO}_{4}{ }^{0}$ and potential $\mathrm{Si}$ adsorbed polymers.

We cannot rule out that desorption occurred during our experiment. Since the experimental device was not designed to assess the impact of Si desorption on Si-isotopic fractionation it would be hazardous to extrapolate our results to the desorption process. We believe that the impact of desorption would be minor on our isotopic data because (i) the adsorption curves showed very regular patterns in accordance with adsorption as the main process driving silicon content in the solution (Fig. 5) (Hansen et al., 1994a,b); (ii) most of the data were acquired for $f>0.5$ which should favor adsorption over desorption before saturation of sites is reached (Hansen et al., 1994a,b); (iii) to impact significantly on our results, desorption should fractionate isotopes at least in the same extent as adsorption which is unlikely. Unfortunately, to the best of our knowledge, there is so far no experimental setting to study isotopic fractionation induced by the sole Si desorption.

\subsection{Environmental significance}

Our data provide unequivocal answers to the four questions of critical environmental significance (see Section 1). $\mathrm{Si}$ isotope fractionation (1) occurs during $\mathrm{Si}$ adsorption onto $\mathrm{Fe}$ oxide at common $\mathrm{pH}$ for soil solutions, (2) is similar or larger to the one generated by $\mathrm{Si}$ uptake by biota, and can thus contribute (3) to the depletion of light $\mathrm{Si}$ isotopes in river waters, and (4) to the relative concentration of light $\mathrm{Si}$ isotopes in soil clay fractions through $\mathrm{Si}$ sorption on pedogenic Fe oxides. Our data further suggest that the concentration of light $\mathrm{Si}$ isotopes in soil clay-sized fractions (Ziegler et al., 2005a,b; Opfergelt et al., accepted for publication) can be at least partly due to $\mathrm{H}_{4} \mathrm{SiO}_{4}{ }^{0}$ sorption onto secondary iron oxides.

Silicon adsorption by soil $\mathrm{Fe}$ oxides is thus a process which may partly control the depletion of light $\mathrm{Si}$ isotope in river waters, in addition to clay formation (Ziegler et al., 2005b; Georg et al., 2006, 2007), Si uptake by plants (Ding et al., 2005; Opfergelt et al., 2006a) and diatoms (Alleman et al., 2005). However, impact of Si adsorption on the Si-isotopic budget will be strongly limited if oxide surfaces are Si-saturated as shown experimentally with ${ }^{32} \mathrm{Si}$ (Ziegler et al., 2005a). Ferrihydrite and goethite are sparingly soluble constituents of weathered rocks and soils, with solubility products in the range $10^{-38}$ to $10^{-46} \mathrm{M}$ (Schwertmann and Taylor, 1989). In well drained conditions, Fe released from weathered parent material is thus poorly mobile and accumulates in soils as secondary Fe(III) minerals: Fe oxides rapidly precipitate as discrete solid phases from the weathering solution of decomposed primary silicates. As inferred from studies on the adsorption of dissolved organic matter, juvenile oxide surfaces are very effective to adsorb 
solutes with which they specifically interact (Guggenberger and Kaiser, 2003). Rock weathering and soil development lead to the formation of both clay minerals and secondary oxides. These processes may thus add their mutual isotopic effects to significantly impact the $\mathrm{Si}$-isotopic signature of drained waters. Weathered soil and saprolite layers thus acquired a high propensity to impact soil solutions and exported waters through $\mathrm{Si}$ adsorption. As an example, $\mathrm{Si}$ adsorption could have impacted isotopic signatures of Siberian rivers draining iron-rich swamp zones and peat soils of the permafrost landscape, which are found to be strongly enriched in heavy $\mathrm{Si}$ isotopes compared to basaltic bedrock (Reynolds et al., 2006).

Si stable isotopes thus constitute a promising tracer with respect to three major processes involved in the weathering environment: biological fractionation during plant phytolith formation (Ding et al., 2005, 2008; Opfergelt et al., 2006a), sequestration of Si in soil clay-sized minerals (Ziegler et al., 2005a,b; Opfergelt et al., accepted for publication), and adsorption of $\mathrm{Si}$ by pedogenic iron oxyhydroxides (this study). A similar statement concerns the $\mathrm{Ge} / \mathrm{Si}$ ratio as a weathering tracer (Mortlock and Froelich, 1987; Scribner et al., 2006; Derry et al., 2005). The impact of weathering stage, soil development and free iron oxide availability on the $\mathrm{Si}$-isotopic composition of source and river waters thus deserves further field-based studies to progress in the appraisal of the silicon continental cycle.

\section{CONCLUSION}

The adsorption of $\mathrm{H}_{4} \mathrm{SiO}_{4}{ }^{0}$ by ferrihydrite and goethite at $\mathrm{pH} 5.5$ strongly fractionates $\mathrm{Si}$ isotopes by selectively adsorbing light isotopes and leaving a companion solution enriched with heavy $\mathrm{Si}$ isotopes. The isotope fractionation of silicon is similar to or slightly larger than that generated by Si uptake by plants and diatoms. We suggest that the concentration of light $\mathrm{Si}$ isotopes in soil clay-sized fractions is at least partly due to $\mathrm{H}_{4} \mathrm{SiO}_{4}{ }^{0}$ sorption onto secondary iron oxides. We conclude that rock weathering and soil development could impact the Si-isotopic signature of natural waters drained to streams through Fe oxide synthesis, as oxide surfaces specifically interact with aqueous monosilicic acid. Although occurring at very different time scales (from the rainy event to the soil formation), the processes of pore water drainage, clay-sized Fe oxide formation and $\mathrm{Si}$ adsorption would significantly impact the Si-isotopic signal to oceans, as continental runoff water contributes to more than $80 \%$ of the $\mathrm{Si}$ input to the marine Si budget (Tréguer et al., 1995).

In the future, the $\mathrm{Si}$-isotopic fractionation induced by adsorption onto Al-oxides and in natural soils should also be investigated along with the impact of desorption.

\section{ACKNOWLEDGMENTS}

We greatly thank N. Mattielli and J. de Jong (ULB) for managing the MC-ICP-MS facility in ULB, A. Iserentant and C. Givron (UCL), L. Monin and N. Dahkani (MRAC) for laboratory assistance, and F. Trum (UCL) for SAS computing calculation. This manuscript has greatly benefited from the constructive comments of J. Farquhar and of three anonymous reviewers. S.O. is supported by the "Fonds National de la Recherche Scientifique" (FNRS) of Belgium and D.C. by the Federal Belgian Science Policy. The $\mathrm{Si}$ isotopes methodology has been set up owing to various supports from BELSPO (EV/37/7C), FNRS (FRFC 2.4.512.00F), the EC (EVK-CT-2000-00057). This research was supported by the FNRS research convention No. 2.4629.05 and by the "Fonds Spécial de Recherche" (FSR) 2005 of the UCL. The authors thank all these funding agencies for their financial support.

\section{REFERENCES}

Alleman L. Y., Cardinal D., Cocquyt C., Plisnier P. D., Descy J. P., Kimirei I., Sinyinza D. and André L. (2005) Silicon isotopic fractionation in Lake Tanganyika and its main tributaries. $J$. Great Lake Res. 31, 509-519.

Anderson P. R. and Benjamin M. M. (1985) Effects of silicon on the crystallization and adsorption properties of ferric oxides. Environ. Sci. Technol. 19, 1048-1053.

Barling J. and Anbar A. D. (2004) Molybdenum isotope fractionation during adsorption by manganese oxides. Earth Planet. Sci. Lett. 217, 315-329.

Basile-Doelsch I. (2006) Si stable isotopes in the Earth's surface: a review. J. Geochem. Explor. 88, 252-256.

Basile-Doelsch I., Meunier J.-D. and Parron C. (2005) Another continental pool in the terrestrial silicon cycle. Nature 433, 399 402.

Beckwith R. S. and Reeve R. (1963) Studies on soluble silica in soils: I. The sorption of silicic acid by soils and minerals. Aust. J. Soil Res. 1, 157-168.

Bikerland P. W. (1974) Pedology, Weathering and Geomorphological Research. Oxford University Press, New York.

Blakemore L. C., Searle P. L. and Daly B. K. (1981) Methods for Chemical Analysis of Soil. New Zealand Soil Bureau scientific Report $10 \mathrm{~A}, 2$ nd revision.

Bolan N. S., Barrow N. J. and Posner A. M. (1985) Describing the effect of time on sorption of phosphate by iron and aluminium hydroxides. J. Soil Sci. 36, 187-197.

Cardinal D., Alleman L. Y., De Jong J., Ziegler K. and André L. (2003) Isotopic composition of silicon measured by multicollector plasma source mass spectrometry in dry plasma mode. $J$. Anal. Atom. Spectrom. 18, 213-218.

Carignan J., Cardinal D., Eisenhauer A., Galy A., Rehkamper M., Wombacher F. and Vigier N. (2004) A reflection on Mg, Cd, $\mathrm{Ca}, \mathrm{Li}$ and $\mathrm{Si}$ isotopic measurements and related reference materials. Geostand. Geoanal. Res. 28, 139-148.

Carter D. L., Heilman M. D. and Gonzalez C. L. (1965) Ethylene glycol monoethyl ether (EGME) for determining specific surface of silicate minerals. Soil Sci. 100, 356-360.

Cornell R. M. and Schwertmann U. (1996) The Iron Oxides: Structure, Properties, Reactions, Occurence and Uses. VCH, Weinheim and New York.

Davis C. C., Chen H. W. and Edwards M. (2002) Modeling silica sorption to iron hydroxide. Environ. Sci. Technol. 36, 582-587.

De La Rocha C. L., Brzezinski M. A. and De Niro M. J. (1996) Purification, recovery, and laser-driven fluorination of silicon dissolved and particulate silica for the measurement of natural stable isotope abundances. Anal. Chem. 68, 3746-3750.

De La Rocha C. L., Brzezinski M. A. and De Niro M. J. (1997) Fractionation of silicon isotopes by marine diatoms during biogenic silica formation. Geochim. Cosmochim. Acta 61, 50515056.

De La Rocha C. L., Brzezinski M. A. and De Niro M. J. (2000) A first look at the distribution of the stable isotopes of silicon in natural waters. Geochim. Cosmochim. Acta 64, 2467-2477. 
Delfosse T., Delmelle P., Givron C. and Delvaux B. (2005) Inorganic sulphate extraction from $\mathrm{SO}_{2}$-impacted andosols. Eur. J. Soil Sci. 56, 127-133.

Derry L. A., Kurtz C. A., Ziegler K. and Chadwick O. A. (2005) Biological control of terrestrial silica cycling and export fluxes to watersheds. Nature 433, 728-730.

Dietzel M. (2002) Interaction of polysilicic and monosilicic acid with mineral surfaces. In Water-Rock Interaction (eds. I. Stober and K. Bucher). Kluwer Academic Publishers, pp. 207-235.

Ding T., Wan D., Wang C. and Zhang F. (2004) Silicon isotope compositions of dissolved silicon and suspended matter in the Yangtze River, China. Geochim. Cosmochim. Acta 68, 205-216.

Ding T. P., Ma G. R., Shui M. X., Wan D. F. and Li R. H. (2005) Silicon isotope study on rice plants from the Zhejiang province, China. Chem. Geol. 218, 41-50.

Ding T. P., Zhou J. X., Wan D. F., Chen Z. Y., Wang C. Y. and Zhang F. (2008) Silicon isotope fractionation in bamboo and its significance to the biogeochemical cycle of silicon. Geochim. Cosmochim. Acta 72, 1381-1395.

Douthitt C. B. (1982) The geochemistry of the stable isotopes of silicon. Geochim. Cosmochim. Acta 46, 1449-1458.

Fuller C. C., Davis J. A. and Waychunas G. A. (1993) Surface chemistry of ferrihydrite: part 2. Kinetics of arsenate adsorption and coprecipitation. Geochim. Cosmochim. Acta 57, 2271-2282.

Gaillardet J., Dupré B. and Allègre C. J. (1999) Geochemistry of large river suspended sediments: silicate weathering or recycling tracer? Geochim. Cosmochim. Acta 63, 4037-4051.

Galy A., Pokrovsky O. S. and Schott J. (2002) Ge-isotopic fractionation during its sorption on goethite: an experimental study. Geochim. Cosmochim. Acta 66(15), A259, Suppl. 1.

Garman S. M., Luxton T. P. and Eick M. J. (2004) Kinetics of chromate adsorption on goethite in the presence of sorbed silicic acid. J. Environ. Qual. 33, 1703-1708.

Gehlen M. and Van Raaphorst W. (2002) The role of adsorptiondesorption surface reactions in controlling $\mathrm{Si}(\mathrm{OH})_{4}$ concentrations and enhancing $\mathrm{Si}(\mathrm{OH})_{4}$ turn-over in shallow shelf seas. Cont. Shelf Res. 22, 1529-1547.

Georg R. B., Reynolds B. C., Frank M. and Halliday A. N. (2006) Mechanisms controlling the silicon isotopic compositions of river waters. Earth Planet. Sci. Lett. 249, 290-306.

Georg R. B., Reynolds B. C., West A. J., Burton K. W. and Halliday A. N. (2007) Silicon isotope variations accompanying basalt weathering in Iceland. Earth Planet. Sci. Lett. 261, 476490.

Guggenberger G. and Kaiser K. (2003) Dissolved organic matter in soil: challenging the paradigm of sorptive preservation. Geoderma 113, 293-310.

Hansen B. H. C., Raben-Lange B., Raulund-Rasmussen K. and Borggaard O. K. (1994a) Monosilicate adsorption by ferrihydrite and goethite at pH3-6. Soil Sci. 158, 40-46.

Hansen H. C. B., Wetche T. P., Raulund-Rasmussen K. and Borggaard O. K. (1994b) Stability-constants for silicate adsorbed to ferrihydrite. Clay Miner. 29, 341-350.

Henriet C., Draye X., Oppitz I., Swennen R. and Delvaux B. (2006) Effects, distribution and uptake of silicon in banana (Musa spp.) under controlled conditions. Plant Soil 287, 359-374.

Hiemstra T., Barnett M. O. and van Riemsdijk W. H. (2007) Interaction of silicic acid with goethite. J. Colloid Interface Sci. 310, 8-17.

Hingston F. J., Posner A. M. and Quirk J. P. (1972) Specific adsorption by goethite and gibbsite. I. The role of the proton in determining adsorption envelopes. J. Soil Sci. 23, 177-192.

Hingston F. J., Atkinson R. J., Posner A. M. and Quirk J. P. (1967) Specific adsorption of anions. Nature 215, 1459-1461.

Hofmann A., Pelletier M., Michot L., Stradner A., Schurtenberger P. and Kretzschmar R. (2004) Characterization of the pores in hydrous ferric oxide aggregates formed by freezing and thawing. J. Colloid Interface Sci. 271, 163-173.

Jambor J. L. and Dutrizac J. E. (1998) Occurrence and constitution of natural and synthetic ferrihydrite, a widespread iron oxyhydroxide. Chem. Rev. 98, 2989-2990.

Jones L. H. P. and Handreck K. A. (1963) Effects of iron and aluminium oxides on silica in solution in soils. Nature 198, 852-853.

Lemarchand E., Schott J. and Gaillardet J. (2007) How surface complexes impact boron isotope fractionation: evidence from $\mathrm{Fe}$ and $\mathrm{Mn}$ oxides sorption experiments. Earth Planet. Sci. Lett. 260, 277-296.

Lijklema L. (1980) Interaction of orthophosphate with iron (III) and aluminium hydroxides. Environ. Sci. Technol. 41, 537-541.

Lindsay W. L. (1979) Chemical Equilibria in Soils. Wiley Interscience, New York.

Luxton T. P., Tadanier C. J. and Eick M. J. (2006) Mobilization of arsenite by competitive interaction with silicic acid. Soil Sci. Soc. Am. J. 70, 204-214.

McBride M. B. (1994) Environmental Chemistry of Soils. Oxford University Press, New York, pp. 406.

McKeague J. A. and Cline M. G. (1963) Silica in soils. Adv. Agron. 15, 339-396.

Mehra O. P. and Jackson M. L. (1960) Iron oxides removal from soils and clays by dithionite-citrate system buffered with sodium bicarbonate. In Proc. 7th Natl. Conf. Clays Clay Minerals, Washington, pp. 317-327.

Mortlock R. A. and Froelich P. N. (1987) Continental weathering of germanium: $\mathrm{Ge} / \mathrm{Si}$ in the global river discharge. Geochim. Cosmochim. Acta 51, 2075-2082.

Opfergelt S., Cardinal C., Henriet C., Draye X., André L. and Delvaux B. (2006a) Silicon isotope fractionation by banana (Musa spp.) grown in a continuous nutrient flow device. Plant Soil 285, 333-345.

Opfergelt S., Cardinal D., Henriet C., André L. and Delvaux B. (2006b) Silicon isotope fractionation between plant parts in banana: in situ vs. in vitro. J. Geochem. Explor. 88, 224-227.

Opfergelt S., Delvaux B., André L. and Cardinal D. (in press) Plant silicon isotopic signature might reflect soil weathering degree. Biogeochemistry. doi:10.1007/s10533-008-9278-4.

Parfitt R. L. (1978) Anion adsorption by soils and soil materials. Adv. Agron. 30, 1-50.

Pokrovski G. S., Schott J., Farges F. and Hazemann J. L. (2003) Iron (III)-silica interactions in aqueous solution: insights from X-ray absorption fine structure spectroscopy. Geochim. Cosmochim. Acta 67, 3559-3573.

Pokrovsky O. S., Pokrovski G. S., Schott J. and Galy A. (2006) Experimental study of germanium adsorption on goethite and germanium coprecipitation with iron hydroxide: X-ray absorption fine structure and macroscopic characterization. Geochim. Cosmochim. Acta 70, 3325-3341.

Reynolds B. C., Aggarwal J., André L., Baxter D., Beucher C., Brzezinski M. A., Engström E., Georg B., Land M., Leng M. J., Opfergelt S., Rodushkin I., Sloane H. J., Van den Boorn S. H. J. M., Vroon P. Z. and Cardinal D. (2007) An inter-laboratory comparison of $\mathrm{Si}$ isotope reference materials. J. Anal. Atom. Spectrom. 22, 561-568.

Reynolds B. C., Pokrovsky O. S. and Schott J. (2006) Si isotopes for tracing basalt weathering in Central Siberia. Geochim. Cosmochim. Acta 70(18), A528, Suppl. 1.

Schwertmann U. and Taylor R. M. (1989) Iron oxides. In Minerals in Soil Environments (eds. J. B. Dixon and S. B. Weed). Soil Science Society of America Madison, Wisconsin, pp. 379-438.

Schwertmann U., Cambier P. and Murad E. (1985) Properties of goethites of varying crystallinity. Clay Clay Miner. 33, 369-378.

Scott K. M., Lu X., Cavanaugh C. M. and Liu J. S. (2004) Optimal methods for estimating kinetic isotope effects from different 
forms of the Rayleigh distillation equation. Geochim. Cosmochim. Acta 68, 433-442.

Scribner A. M., Kurtz A. C. and Chadwick O. A. (2006) Germanium sequestration by soil: targeting the roles of secondary clays and Fe-oxyhydroxides. Earth Planet. Sci. Lett. 243, 760-770.

Siebert C., Nägler T. F., von Blankenburg F. and Kramers J. D. (2003) Molybdenum isotope records as a potential new proxy for paleoceanography. Earth Planet Sci. Lett. 211, 159171.

Sigg L. and Stumm W. (1981) The interaction of anions and weak acids with the hydrous goethite $(\alpha-\mathrm{FeOOH})$ surface. Colloids Surf. A 2, 101-117.

Stumm W. and Morgan J. J. (1996) Aquatic Chemistry - Chemical Equilibria and Rates in Natural Waters. Wiley, New York.

Swedlund P. J. and Webster J. G. (1999) Adsorption and polymerisation of silicic acid on ferrihydrite, and its effect on arsenic adsorption. Water Res. 33, 3413-3422.

Tréguer P., Nelson D. M., Van Bennekom A. J., De Master D. J., Leynaert A. and Queguiner B. (1995) The silica balance in the world ocean: a reestimate. Science 268, 375-379.
Waltham C. A. and Eick M. J. (2002) Kinetics of arsenic adsorption on goethite in the presence of sorbed silicic acid. Soil Sci. Soc. Am. J. 66, 818-825.

Weber J. W. J., McGinley P. M. and Katz L. E. (1991) Sorption phenomena in subsurface systems: concepts, models and effect on contaminant fate and transport. Water Res. 25, 499-528.

Willett I. R., Chartres C. J. and Nguyen T. T. (1988) Migration of phosphate into aggregated particles of ferrihydrite. J. Soil Sci. 39, 275-282.

Ziegler K., Chadwick O. A., Brzezinski M. A. and Kelly E. F. (2005a) Natural variations of $\delta^{30} \mathrm{Si}$ ratios during progressive basalt weathering, Hawaiian Islands. Geochim. Cosmochim. Acta 69, 4597-4610.

Ziegler K., Chadwick O. A., White A. F. and Brzezinski M. A. (2005b) $\delta^{30} \mathrm{Si}$ systematics in a granitic saprolite, Puerto Rico. Geology 33, 817-820.

Associate editor: James Farquhar 